\title{
A Literary Inquiry into Disability, Trauma and Narrative Strategies in Lisa Genova's Novels
}

Mrs. Koyyana Pallavi

Ph.D Research Scholar

Department of English

Arts and Commerce

Andhra University

Andhra Pradesh, India

dr.pallavi2021@gmail.com

Prof. Y. Somalatha

Research Guide

Department of English

Arts and Commerce

Andhra University

Andhra Pradesh, India

The memory is but a passing ghost.

Lisa Genova, Every Note Played

\begin{abstract}
The reaisltic illustration of central characters suffering from rare and severe neurological sicknesses in Lisa Genova's novels provide an ideal prospect to study trauma in pathography novels, a subset of science fiction. However, despite its scope, these genres of novels have received little consideration in American literary trauma studies. This paper will present a
\end{abstract}


new analysis of trauma in relationship to the 'neuro'genre, followed by an analysis of narrative and literary devices employed by the author to illustrate traumatic episodes in her novels. Through this case study and critical reflection of how the author has engaged trauma in the novels supports strengthening literary trauma theory within trauma literature and the genre also. The writing of traumatic experiences of the victims, transformed identity, stigmas, fears and phobias and providing face to the sufferer doomed fate, offers an opportunity for a neuroscientist turned novelist like Lisa Genova to advocate about the neurological sicknesses and its suffering with enriched empathetic experience to the non-scientific societies. It also provides a balanced realistic narrative platform for the reader to reflect on their own uncertainties, brought on by the representation of such fictional characterization. This literary research analysis will provide scope to science fiction authors, particularly those aiming to engage with medicine and literature, for a more accurate depiction of trauma in their work. It will further broaden the scope of research in phenomenology, narrative and genre theories and criticism in literary studies.

Keywords: Trauma, Trauma Theory, Narrative devices, Genre, Novel, Pathography, Science Fiction, Medicine and Literature Introduction

According to Laurie Vickroy, trauma literature includes "fictional narratives that help reader to access traumatic experience" (Trauma and Survival in Contemporary Fiction 1). Trauma fiction and neuro fiction as a new phenomenon makes a new entrant in contemporary literary research worldwide. It starts a novel perspective of change in the path of suffering and pain continue to reach to a point of knowledge and understanding. Traumatic experience in such literature is frequently linked with events of pain and suffering related to disability and disease form the key subject matter of the author's fiction. These associations suggest that neuro fiction functions as an ideal vehicle for representing trauma, which provides an 
opportunity for such fiction to offer empathetic benefits to its readers. This paper contests on investigating narrative strategies employed by author like Lisa Genova to mimic trauma in her novels about disease and disability.

Within the framework of trauma theory and its relationship to literature, science and disability fiction, the article compares similar trauma narratives and devices that are used in novels of another genre which are already classified as trauma literature. An analysis of neuronovels written by Lisa Genova together with the narrative strategies used in trauma literature including fragmentation, repetition and characterization are studied. It further investigates deep into the strategies and methods employed by the similar authors of trauma literature, where the genre in neuro fiction may emerge as a new subsection of trauma literature that has the potential to bring transformative to its readers.

Trauma Genre

Before discussing the specific narrative, strategies employed byLisa Genova's in her novels, it is important to understand what trauma is and what trauma genre generally comprises. According to American Psychiatry Association (DSM V), the description of trauma is linked to the direct or indirect exposure of traumatic and stressful event (271). The primary focus of this definition lies in the event and its suffering. Anna Whitehead defined trauma fiction as "a paradox or contradiction: if trauma comprises an event or experience which overwhelms the individual and resists language or representation (Trauma Fiction 3)". Trauma narratives raise important questions about the possibility of verbalizing the unspeakable, narrating the unnarratable, and making sense of the incomprehensible.

According to literary critics Alan Gibbs, trauma narratives in postmodern era is fascinated with the experimental forms employed in the representation of trauma becomes the primary motivation for literary production (Contemporary American Trauma Narratives). Modern psychology also emphasizes the importance of trauma narratives as a means "to learn 
to cope with memories by emotionally processing emotional content ... to understand their trauma and make it meaningful" (Buiteleir 322). Similar arguments were laid by Hubert Zapf who stated that literary trauma texts may have a particular impact on readers precisely because they operate in an imaginary and textual realm.

[Twentieth-century trauma narratives] remain connected, at least in principle, to a long tradition of literary representations of 'other people's pain', whose ethical implications are tied to their fictional status and to the fact that the other people and their fates whose pain the reader is witnessing or sharing are the fates of imaginary people in a depragmatized and metadiscursive space of textuality, which however may paradoxically enhance its communicational intensity and its signifying power towards a collectively experienced historical reality. (166)

To some extent, a shift in focus within trauma studies has occurred since the 1990s where some studies after Caruth and Felman have engaged with narration and recovery with less scepticism. Though the foundational reference to the genre began with the Holocaust studies, it adapted various perspectives and models that includes historical, political, cultural, aesthetics, ethical, autobiographical, etc during the course of time. For example, in Literary Trauma: Sadism, Memory, and Sexual Violence in American Women's Fiction, Deborah Horvitz's readings of women's trauma writings identify “the protagonists' varying capacities to use art, especially narrative, as a method of 'working through' or healing from trauma" as a recurrent trope (18). Another more recent study in trauma studies is Jennifer Griffiths Traumatic Possessions, which explores processes of recovering from trauma and reconstituting the self, with a focus on the role of the body. One important way of further overcoming trauma theory's limitations regarding narration and recovery is to turn to psychological and psychiatric approaches to trauma. 
The novels discussed in this study share some of the concerns of psychological studies, including a focus on individual processes, on the dynamics and crises of memory and identity, and on how trauma victims reconstruct their life-stories around. The two-pronged approach to reading trauma narratives may help to bridge the gap between neuronarrative genre and certain theoretical trajectories, allowing us to redefine trauma less as a general cultural condition and more as a specific, multi-faceted and complex aspect of human experience.

Genova's novels at the junction between trauma and disability genre:

Recent decades, a significant attention has been given to what Macro Roth said, in 2009 , to the term 'neuronovel' also called as syndrome novel (as identified by Lustig and Peacock). According to Roth, what was previously referred to as the psychological novel, the novel of consciousness or the confessional novel, "has transformed itself into the neuronovel, wherein the mind becomes the brain"(The Rise of the Neuronovel). Roth's analysis is adapted by many critics across disciplines, where Francisco Ortega and Fernando Vidal classifies as 'neuro disciplines'. They argue:

Since the 1990s, several disciplines, from neuroanthropology to neurotheology, have emerged at the interface between neuroscience and the social and human sciences. These "neurodisciplines" share basic assumptions about the brain/mind relationship, a preference for neuroimaging methodology, and the goal of establishing the neurobiological foundations of mind and behavior. (Brains in Literature/Literature in the Brain 327)

Lisa Genova is a neuroscientist who became famous in recent popular American platform for her fictional pathography. She is typically known as Oliver Sacks of contemporary fiction and Michael Crichton in brain science. She is a yogi, speaker, an empathy warrior and literary advocate of neurological diseases like Alzheimer's, ALS, 
Huntington's. Genova, in the early days of her writing career faced rejection and criticism from publishers, but she turned out to be one of the productive novelists in America today who authored five novels since 2007. Her work is not just acclaimed in the English-speaking world but has been translated in more than thirty-five languages. Yet, very little research has been conducted on the author's work in the field of literature.

Genova, as a scientist and novelist made a significant impact by creating new trends in American fiction. Her scientific temperament and artistic skills are resourcefully blended in all her novels, Still Alice (2007), Left Neglected (2011), Love Anthony (2012), Inside the O’ Briens (2015) and Every Note Played (2018) to create awareness and empathy about rare and severe medical conditions on its readers. In fact, the experience of the author as a scientist created a new subgenre within neuronovels. All the five novels analyzed in this article focus on the narrative techniques employed by the author to represent trauma associated with chronic sickness, and its influence on the life of the victims and its surrounded characters. As we read the novels, we can see the author incorporating some unique narrative techniques such as nonlinear narration through interference of flashbacks, foreshadowing and dreams, deviated time temporality, interpretations of omniscient narrator, dead/ghost narrator etc. in relation to writing traumatic experience, which deviates from typical conventional styles. Indeed, depiction of trauma using these techniques is not new in trauma studies, but this article will reflect Genova's novels, as a new subset, in perspective of trauma fiction which captures the traumatic experience of the vulnerable that involves physical, psychological and emotional suffering.

The question that comes in the way of whether or not it is appropriate to consider Lisa Genova's novels as neuronovels, I would suggest based on the broadly accepted description of the genre to focus on the fresh representation of brain and consciousness. For the author like Lisa Genova, neuroscience has turned out to be a creative tool to advocate the 
sensibilities central to neurological diseases, cognitivity and disability by creating realistic characters in her novels. Neuroscience is the heart of the author's novels and is written in a free indirect discourse which remains very close to its main characters, is able to break off in order to meditate occasionally on neurological and medical facts before returning to a more well-recognized form of narration. Her novels are written in first-person or close third-person narration, so that consciousness and the way that it is understood and represented forms a significant part of the narrative. The study of genre is in itself diverse and complex, and needs individual attention and beyond the scope of this research paper. But Racheal Holland in her book Contemporary Fiction and Science from Amis to Mc Ewan: The Third Culture labelled that neuronovels stand out away from science fiction in way, "since the 'neuro' part of each novel is utilized by their authors as a tool with which to maintain the status and reputation of the novel, rather than as a generic framework" (83).This helps to give reason for positioning Genova's novels within this new genre or subgenre of neuronovels.

The reasons for associating Lisa Genova's neuronovel to trauma literature are because both the genres display duality in their storyline. On one side of the story, it handles the traumatic event, memories and identity that is typical to trauma literature and the disease and disability as traumatic event which in many recent studies associated with PTSD, while on the other side attempts to reconstruct the event to adapt and survive. This parallel creates an entry point of the author's novels to fit into trauma literature.

Lisa Genova's novels are self-reflective psychological narratives that tell us the story of individual and collective experience with chronic neurological conditions and its devasting effects. Her novels are filled with diseased and disabled individuals whose weakening bodies and consciousness prevent them from being themselves. For trauma scholars, these novels represent a complex psychological perspective on medical conditions, which seemed to drift 
away from trauma discourses for a while, yet to date, no literary scholar have explored the relevance of neuronarratives to trauma.

Narrative language on disability

Despite of reading Genova's novels as neuronarrtives, I propose to consider her novels with a closed attention to disease and disability. In order to sustain this argument, one needs to identify critical vocabulary on disease and disability into existing discussion about trauma, memory and identity in Genova's novels. Such a vocabulary, however, remains vague. As James Berger argues, a "discursive abyss" separating disability studies from trauma studies has resulted in two separate and disconnected theoretical discussions about frequently overlapping phenomena (563). Within disability studies, this discursive abyss manifests itself in the absence of a sustained inquiry into trauma and loss. Berger comments on the political origins of disability studies- namely, its links with the disability rights movement in the US, its critique of oppressive discourses that have constructed the absolute alterity of those who live with disabilities, and its concern with "achieving equal access to full social, professional, and political lives" for disabled individuals-has taken precedence over an exploration of the "particularities of loss" of any one individual. Indeed, these political goals have resulted in a reluctance to admit that disability is at times accompanied by feelings of loss, fear, or mourning. Berger finds this omission somewhat "remarkable":

Not all instances of disability are traumatic, certainly not in a direct way. But many are, such as those produced by war, accident, and sudden debilitating illness, both for the individuals affected and for their families ... A theory of disability might well try to include a theory of loss specific to disability-that is, the loss of physical, mental, and neurological capacities. The world itself, and one's own body, must be relearned, processes clearly analogous to some of the central concerns of trauma studies. One would think that a theory of disability would address such questions of 
trauma, loss, mourning, and regeneration that seem so closely associated with many people's experiences of disability. (572)

This research investigates Genova's neuronovels at the junction of disability and trauma studies. Reading the author's novels with this integration aid to explain the influential empathetic responses among its readers. Her novels also explore the expression of adaptation and survival symbolised by their transitional journey from the world of normalcy to disability, suggests novel directions for both trauma and disability studies.

Some recent critics pointed that author like Lisa Genova deviates from the traditional fictional writing with scientific temperament, while maintaining both 'neuroscience and human spirit' at the core of her novels. Her novels received a noticeable amount of reception from both literary and non-literary platforms. Daily mail describes her debut novel Still Alice "frightening to read" (Clare Colvin). Similarly, Brunonia Barry, New York Times bestselling author of The Lace Reader, described it as "a story that must be told" and "heartbreakingly real". Although her novels are marketed as stories about diseases, "readers will find comfort on the beauty of Genova's prose and ability to create profound emotional moments" (Winnipeg Free Press). USA today commented that "Genova is the master of getting into the heads of her characters, relating from the inside out ... brilliantly" .She authored five celebrated novels till date where her "characters live out our nightmarethey lose the ability to think and move, they forget the people they love, they suffer excruciating pain, and they learn that their children have inherited the same fatal disease" (Emily Esfahani Smith). Laura Lippman, author of And When She Was Good, pointed that "Lisa Genova had essentially created her own genre", where all her novels are intertwined with science, humanity and emotions. Her novels can be brought into the new perspective of trauma literature because the narrative structures she employs are fragmented. Genova's novels fit aptly into trauma genres because they depict the testimonies of traumatised 
characters, non- linear plot pattern between the past, present and future. Her characters travel between their symptom free glorious past to the horrid present. Having considered the broader context of trauma within the genre, some specific narrative strategies employed are now investigated using the novels of Lisa Genova as case study. This study does not provide an exhaustive list of strategies used but attempts to showcase prominent literary tools to consider her writing into trauma literature.

One of the central themes of Lisa Genova's novels is to explore the psychological impact of neurological diseases on individual's life, relationships, emotions and empathy. Her novels are filled with description of mind and bodily manifestation of symptoms and neurological deformity of its characters. In her novel Inside the O'Briens, on the very first page, the narrator gives us the description of the protagonist Joe O'Brien, whose eyes bring back the memories of "devil" in his mother "that used to terrify him as a young boy" (6). One of the emblematic features in the author's novel is to advertise memories with "mental instability and impending insanity" (Still Alice131-32). The phrase 'silenced wounds' in the novel Every Note Played gives us another evidence about the powerful image of suffering with roots in the psychology of trauma within the author's narratives (207). Her novels conceptualize psycho-social context of trauma due to disease and disability. Hence, they become an alternative witness of corporeal texts.

Lisa Genova's novels and her narrator's witness can be brought into the literary tradition of testimony within trauma studies. According to literary theorists Shoshana Felman and Dori Laub, testimony are stories told of personal experiences with significant historical traumas(Testimony: Crises of witnessing in literature, psychoanalysis, and history).Their approach builds from at least three underlying assumptions: one, that testimony is the written record of an experience; two, that the reader has some emotional distance from the testimony being offered in the literature, and, three, that the confrontation with immense trauma such as 
the disease, disability and death as in this case study demands that the reader serve as witness. A reader's witnessing might involve empathetic emotional responses that acknowledge the importance of the stories told. Situating the author's novels within the framework of testimony raises such central questions as the possibility of representation in the trauma, disease and disability and the relationship of individual memory to collective witness.

In Lisa Genova's neuronovels, the term 'disability' provides of an accurate and lifelike narration for chronic neurological conditions of victims who are "trapped in the trenches of a battle in which there would be no survivors (Still Alice258)". The disability defined in her characters includes body, mind and brain transcending into a permanent fatal impairment. For example, in Left Neglected, the female protagonist Sarah, vice-president of human resources at Berkley Consultancy comments on her changed body and mind due to a rare neurological condition left neglect after a life-threatening accident, "my new mind is broken and doesn't give a whack about the left or my old mind's reputation for success" (155). The strangest thing about sitting in front of this big mirror every day is seeing myself sitting in a wheelchair. Handicapped. I don't feel handicapped, and yet, there I am. (Left Neglected).

No longer she is able to lead "the fast pace, the high intensity, contributing to something important, feeling powerful and sophisticated, being effective", and she is forced to depend on others for her survival (343). Pointing to her disability, Sarah confesses that "I want to dive back in, I'm not willing to compromise the quality of work that the company needs or my reputation for delivering it" (344). The social position of such impaired victims changes as the character labelled. They are vulnerable physically, both individually and collectively.

The novel Still Alice also draws us to similar comparison between a chronic neurological disease, Alzheimer's disease and disability. 
My reality is completely different from what it was not long ago. And it is distorted. The neural pathways I use to try to understand what you are saying, what I am thinking, and what is happening around me are gummed up with amyloid. I struggle to find the words I want to say and often hear myself saying the wrong ones. I can't confidently judge spatial distances, which means I drop things and fall down a lot and can get lost two blocks from my home. And my short-term memory is hanging on by a couple off rayed threads. "I'm losing my yesterday. (Still Alice281)

As the protagonist of the novel worries "Is my soul and spirit immune to the ravages of Alzheimer's? I believe it is."Being diagnosed with Alzheimer's is like being branded with a scarlet A. This is now who I am, someone with dementia. This was how I would, for a time, define myself and how others continue to define me (Still Alice282)". Such a disability doesn't kill them but make them impaired with its consequences. We can comprehend Alice's, once a successful professor's, suffering including cognitive as well as emotional pain, and the daily experience of living in changing brain in many ways which makes her forget her yesterdays.

Hence, Genova's novels portray the inner struggle of the character's accept their permanently altered neurological identity. It constitutes the central dramatic part of the author's advocacy to empathise loss and loneliness. Focusing on such experiences enables the readers to better understand the ways in which their neurological transformation is associated to their identity and body.

Fragmentation

According to Goldsmith and Satterlee, fragmentation is one strategy employed to "convey the fracturing of time, self and reality that ... accompanies traumatic episodes or recall" using literary devices such as analepsis (or flashbacks), non-linear narrative, delayed narrative or textual gaps (Representation of Trauma 45). Fragmentation is one of the common 
narrative strategies employed by Genova in all her novels. This narrative strategy in this involves analepsis or flashbacks to move the reader between and the past and present. The narration lies between simple to complex, where the narrator or characters reveal some raw traumatic truths about living with neurological disease thereby creating complexity. In her debut novel Still Alice, the narrative forwards in a span of fast-paced liner manner between September 2003 and September 2005, following traditional narrative style, but its mutiny lies using analepsis to move the reader occasionally past September 2003. The narration bumps into the past, revealing Alice Holland's once cherished life, creating density for the reader to interpret.

Likewise, in another Genova's non-linear narrative Inside the O'Brien, flashbacks about Joe O'Brien's mother horror, her impulsiveness and violent episodes, Joe's unpredictability, family secret to Huntington's disease that his father concealed from the family and society engages it with the theme."And in that empty space emerges an image of his mother. A memory" (Inside the O’Briens 289)

Going beyond the typical narrative style, Genova uses analepsis to mimic the way the traumatic recall surrounding events affects Joe's life, allowing readers to bear witness to his psychological and physical torment due to the disease. He also harbours the guilt of sharing his monstrous HD gene with his children and which the narrator describes as a "bleeding wound in Joe's gut" (202). Secondly, he carries the guilt of silence about his mother for thirty years.

Joe replays the memory, and he sees his mother again and anew. Unable to walk or feed herself, unable to defend her reputation from the rumors that she was a drunk and a sinner and a bad mother, unable to live at home or hug her kids or tuck them into bed at night, she's smiling with her eyes at Joe. In the end, his mother wasn't just a living corpse waiting to die in a hospital. She was a wife and mother who loved her 
family, grateful to see them and still love them for as long as she could.

Tears stream down Joe's temples, wetting his hair as he remembers his mother, no longer the grotesque monster he despised and blamed and was ashamed of. She was Ruth O'Brien, his mother, a woman who had HD through no fault of her own, who gave her family love and gratitude when she had nothing else to give.

After all these years, he sees his mother. Re-membered. (290)

In her recent novel Every Note Played, Genova steps into further narrative complication as she moves beyond the limits of time by transporting flashbacks to traumatic events in character's lives non-chronologically. She inserts Katrina's traumatic stress memories into the narrative by using triggers as tool. Many of the character's flashbacks are related to her ex-husband Richard and their broken relationship, where Karina describes their relation as 'intoxicating'. "Memories of him haunt her in every room of their once-shared home, the rare good as unsettling as the common bad ... She's exactly where he left her, still living in their house, his energetic impression left behind like a red-wine stain on a white blouse. Even washed a thousand times, that brown spot is never coming out" (Every Note Played 25). Lisa Genova uses this kind of narrative strategies which uses events to trigger traumatic memories, both mentally and bodily.

In comparison to all her novels, the structure of Left Neglected is significantly fastpaced liner narrative. The first six chapters primarily focus on her dreams. The reader is introduced to her stress filled multitasking life, until chapter seven where her everyday normal world is seen to be shattered due to traumatic brain accident leaving her with a rare neurological condition called left neglect. In this novel Genova uses analepsis at time in the form of flashbacks and dreams to depart momentarily from the narrative. She is seen to use double movement in this narrative to backward towards revelation, and forward towards resolution. She depicts traumatic and stressful events on Sarah's life through brief flashbacks, 
including the one on her childhood neglect. However, this narrative is not fragmented in a way that mimics trauma or subverts the plot. The linear structure of Left Neglect prevents the novel from being innovative in terms of form or content, so it cannot be considered as 'difficult'. Thereby, it does not fit the definition of artistic merit.

Characterisation

Susan Senator, author of Making Peace with Autism commented that Genova's characters are complicated people, with unique, believable and, sometimes frustrating struggles. But perhaps Genova's true mastery is in the way she never fails. Dealing with characters, particularly revealing anguish, rage, defeat, and stress, can move the focus of Lisa Genova's novels from plot to characterization. Her novels take up the subject matter of how chronic disease and disability is a brooding ground for individual's trauma and its related attitude and values involving family and society, extends into multi-dimensional emotional effects in the character's disease induced psychological trauma. Genova believes in portraying the details of psychological state of character's mind suffering from disease and disability, and the impact it has on their lives and the people surrounding them.

The main female characters of her novels, Alice, Sarah, Olivia, Katrina are all strong women. In the novel Still Alice, Alice is a brilliant Harvard professor, who is equally committed to her family and profession, yet she fears falling into the demented hole of Alzheimer's disease, meeting her lost self in despair."She could feel herself declining. She could feel herself slipping into that demented hole. Alone."I'm alone, I'm alone, I'm alone," she moaned, sinking further into the truth of her lonely hole each time she heard her own voice say the words" (Still Alice 241). The plot of this novel revolves around Alice's illness and how it impacts her life and the people surrounding her. "I may never be able to retrieve what I've already lost, but I can sustain what I have" (Still Alice 283). She shows great 
conviction in keeping her worth and her identity as long her memory allows with the support of her family.

“I often fear tomorrow. What if I wake up and don't know who my husband is? What if I don't know where I am or recognize myself in the mirror? When will I no longer be me? Is the part of my brain that's responsible for my unique 'meness' vulnerable to this disease? Or is my identity something that transcends neurons, proteins, and defective molecules of DNA? Is my soul and spirit immune to the ravages of Alzheimer's? I believe it is.“Being diagnosed with Alzheimer's is like being branded with a scarlet A. This is now who I am, someone with dementia. This was how I would, for a time, define myself and how others continue to define me. But I am not what I say or what I do or what I remember. I am fundamentally more than that. "I am a wife, mother, and friend, and soon to be grandmother. I still feel, understand, and am worthy of the love and joy in those relationships. I am still an active participant in society. My brain no longer works well, but I use my ears for unconditional listening, my shoulders for crying on, and my arms for hugging others with dementia. (Still Alice282-83).

The character's helpless state allows readers to identify and empathise with the suffering and agony and their traumatically driven plight. The novel explores into the human condition by fixing on the character, thereby meeting the standards for creative worth. Genova's narration is characteristically drawing the narrative around the main characters as victims of chronic illness with disability, going beyond the struggle, and providing clues on adaptation and survival.

In the novel Left Neglected, Genova portrays the protagonist's Sarah Nickerson's childhood traumatic experience around her brother's death by drowning and her mother's abandoning her due to depression in a sympathetic way, painting the character as a victim of 
pain and suffering. The narrative does not dive deep into the effects of these traumatic experiences, but emphasis on adaptation as a scene between Sarah and her mother demonstrates, “My childhood after Nate died wasn't easy, but it made me who I am today: strong, fiercely independent, driven to succeed, determined to matter. I'd managed to put my past behind me" (Left Neglected188). The scene continues into developing the effects of Sarah's suffering and childhood abonnement, how she led an unattended life, having raised by her father alone. However, the author, does not privilege her readers with an elaborative inner journey into the character's suffering mind as does in Inside the O'Brien and Every Note Played. The plot driven in Left Neglected does not fully concentrate on human condition suffering or pain, but on adaptation and survival, hence it cannot fully claim the creative quality of trauma fiction.

Joe O'Brien's triple decker house appears as much a character in Genova'snovel Inside the O'Brien's, as the character. For Joe, the house symbolises 'inheritance' and 'the family'. "It's his family legend and legacy" (Inside the O'Briens 18)". Writers of fiction often employ place as a character motif. Tewksbury State Hospital, is another place used as a motif that brings the memories of Joe's mother and the fatal disease. Lisa Genova with help of the narrative strategy that brings forth the relationship between character's recurrent intrusive flashbacks, allows the readers to the location of character's horrid memories. These horrified imageries to construct the character's motif further supports to arouse traumatic memory.

A memory She's in her shared room in the state hospital, sitting in a padded, reclined wheelchair, a white seat belt over her chest, a black seat belt tight around her waist. She's wearing a short-sleeved blue shirt, swimming on her emaciated frame, a fluorescent-yellow paper bracelet sporting the words FALL RISK around her translucent wrist. Her wrists are pronated, her bony fingers curled and rigid. 
She's sputtering, grunting, pushing out low, wild-animal growls. Her face squeezes fast and tight as if she's been unexpectedly punched. She grunts again and throws her chin up to the ceiling. Her mouth hangs open. Drool drips from her bottom lip onto her blue shirt. (Inside the O'Brien289)

The author continues to paint an austere picture of the house throughout the novel, when she depicts the property in recall of Joe and his family's traumatic memories of the Huntington's disease and his mother, where the house is surrounded by the curse of it takes on threatening characteristics. This also reinforces a strange omniscient feeling that fills Joe, about what happens to him in the future to come, "So what's left for him? Wither in a disgusting stew of shame for years in the living room and then the state hospital, some poor nurse wiping shit off his skinny ass every day until he starves or develops pneumonia and finally dies? What's the point? Why put them all through the miserable shame of it all? (Inside the O'Briens268)". Here one can observe the author's intention use of depicting places and landscapes which symbolises grim, threat and darkness. So, this narrative strategy serves o align the novel with trauma fiction genre where the stylistic language used to personify location as a character set the novel apart from popular genre fiction.

In Every Note Played, there is similar dominance of location where reader can repeatedly return to the site of traumatic experiences. It is a fast-paced linear narrative of genre neuro novel that moves the reader rapidly from scene to scene and between the characters Katrina and Richard. Places personified not only act as a character motif like the before novel, but are also purposed as a setting in which the traumatic action takes place. The room feels strange without Richard in it ... He lived in this room for only four months, but it no longer feels like her den. Richard had ALS in this room. She looks at his empty bed, the wheelchair, his desk chair, and feels his energetic impression everywhere, this room still thick with intense memories of Richard and his ALS. Her 
eyes well, and she rubs the goose bumps on her arms. Or he's decided to haunt her. (Every Note Played 296)

The use of characterisation strategies that use places or locations as a character motif or setting, offers a way for fiction writers like Lisa Genova to discover the themes of trauma and suffering and render her novels with empathetic benefits to its readers.

Conclusion

To conclude, engaging narrative strategies to exemplify trauma in the ways that hold similar purposes to trauma literature offers an opportunity for neurofiction writers, particularly authors like Lisa Genova, who aim to engage with trauma, suffering and fiction, attempts to portray a more authentic representation of trauma in their work. This kind of attempt may enable authors like Genova to be placed in the literary category of trauma literature and open up opportunities for its use as a fiction for therapeutic purposes. The approach has the potentiality to bring transformative benefits to its readers and educate them with empathetic knowledge of trauma, which may transform perceptions, remove stigmas and thereby assist in combating the marginalisation towards such illness and disability. In addition, it provides a safe narrative space for readers to confront their own fears, as they are exposed to traumatic events in more graphic and perilous ways in today's world. This investigation provides a foundation for narrative strategies that lapse the boundaries between genre and literary fiction and leads the way for further research into the potential that narrative has to evoke psychological and emotional growth in treating psychological conditions brought on by trauma. 


\section{Bibliography}

Genova, Lisa. Every Note Played. Allen \& Unwin, 2018

---Left Neglected. Simon \& Schuster, 2011.

--- Inside the O'Briens. Simon \& Schuster, 2015.

--- Still Alice. Simon \& Schuster, 2007.

"Living for All It's Worth: The Novels of Neuroscientist Lisa Genova Explore Love and Empathy.” Writer's Digest, Writer's Digest, 12 Jan. 2018, www.writersdigest.com/writing-articles/living-for-all-its-worth-the-novels-of-lisagenova.

“Still Alice.” Still Alice EBook Online Read, www.bookscool.com/en/Still-Alice-298060/1.

Alan, Gibbs. Contemporary American Trauma Narratives. Edinburgh University Press, 2014, library.lol/main/98416B95EFC402090B135BA66590DA54.

Berger, James. “Trauma Without Disability, Disability Without Trauma: A Disciplinary Divide.” JAC, Vol. 24, No. 3, pp. 563-582., www.jstor.org/stable/20866643.

De Buiteléir, Nóra. "Losing the Plot? The Veteran as Murderer in Bettina Balàka's Eisflüstern.” Journal of War \& Culture Studies, Vol. 6, No. 4, 2013, pp. 313-327., doi:10.1179/1752628013y.0000000002.

Diagnostic and Statistical Manual of Mental Disorders: DSM-5. American Psychiatric Association, 2013, library.lol/main/64CBD980F4001F5A43BA3F992DFC9E9A.

Felman, Shoshana, and Dori Laub. Testimony Crises of Witnessing in Literature, Psychoanalysis and History. Taylor and Francis, 2013.

Goldsmith, Rachel E, and Satterlee Michelle. "Representation of Trauma in Clinical Psychology and Fiction.” Journal of Trauma \& Dissociation, Vol. 5, 2004, pp. 35-59.

Griffiths, Jennifer L. Traumatic Possessions: The Body and Memory in African American Women's Writing and Performance. Univ. of Virginia Press, 2010. 
Holland, Rachel. Contemporary Fiction and Science from Amis to McEwan: The Third Culture Novel. Palgrave Macmillan, 2019, library.lol/main/F2A66CD935B2A803497698F6EDA10111.

Horvitz, Deborah M. Literary Trauma: Sadism, Memory, and Sexual Violence in American Women's Fiction. State University of New York Press, 2000.

Lippman, Laura. Readinggroupguides.com, www.readinggroupguides.com/reviews/loveanthony/praise.

Mail Online, Clare Colvin for. "Lisa Genova: Still Alice.” Daily Mail Online, Associated Newspapers, 6 Apr. 2009, www.dailymail.co.uk/home/books/article-1168042/LisaGenova-Still-Alice.html.

Ortega, F., and F. Vidal. "Brains in Literature/Literature in the Brain." Poetics Today, Vol. 34, No. 3, 2013, pp. 327-360., doi:10.1215/03335372-2325241.

Roth, Marco. "The Rise of the Neuronovel." Recessional, no. 8, 2009, nplusonemag.com/issue-8/essays/the-rise-of-the-neuronovel/.

Vickroy, Laurie. Trauma and Survival in Contemporary Fiction. University of Virginia Press, 2002.

Whitehead, Anne. Trauma Fiction. Edinburgh University Press, 2011. 